\title{
PATHOLOGY/BIOLOGY
}

Leigh Hlavaty, ${ }^{1,2}$ M.D.; Leonardo Roquero, ${ }^{3}$ M.D.; Jeffery Amley, ${ }^{4}$; Kelly Root, ${ }^{1}$; Martin Ishikawa, ${ }^{5}$ M.D.; Andrew Koopmeiners, ${ }^{6}$ M.D.; Lili Zhao, ${ }^{7}$ Ph.D.; and LokMan Sung, ${ }^{1,2}$ M.D.

\section{Discordance of Gross and Histologic Findings in Estimating the Range of Fire of Gunshot Wounds*}

\begin{abstract}
Forensic pathologist use soot and/or stippling surrounding entrance gunshot wounds in categorizing range of fire. If absent, some pathologists suggest utilizing histology when the range is diagnostically critical. This study investigates the concordance of macroscopic and microscopic findings in estimating range of fire by evaluating gunshot entrance and exit wounds made through human tissue analogs at defined distances using two handgun calibers. Examination of over 150 entrance wounds verified the ease of visually detecting soot from a muzzle distance of contact to 1 foot $(30.5 \mathrm{~cm})$, and its absence at 9 feet $(274.3 \mathrm{~cm})$. Distinctly apparent was bullet wipe surrounding the entrance wounds regardless of muzzle distance. Although variations existed, dark material was histologically identified in many skin, soft tissue, and bone sections at all ranges with both calibers. These nonparallel results decrease the dependability of histology for range of fire estimation and reinforce using gross observation.
\end{abstract}

KEYWORDS: forensic science, forensic pathology, histology, close-range firing, gunshot wound, bullet wipe

An important component in the assessment of firearm injuries is examination of the skin surrounding entrance gunshot wounds to establish the range of fire. When a firearm in question cannot be examined and test fired by a firearms examiner, the evaluation of the skin may provide the only estimation to the distance between the muzzle of the weapon and the skin surface. Two established references in forensic pathology divide the range of fire into three categories: contact, close-range, and distant (1); or four categories: contact, near-contact, intermediate, and distant (2). These classifications rely on macroscopic examination of the skin and the findings of abraded margins on these wounds and a muzzle imprint abrasion, soot, and/or gunpowder stippling on the surrounding skin.

\footnotetext{
${ }^{1}$ Wayne County Medical Examiner's Office, 1300 E. Warren Avenue Detroit, MI, 48207.

${ }^{2}$ Department of Pathology, University of Michigan, 1301 Catherine Street, Ann Arbor, MI, 48109.

${ }^{3}$ Clark County Office of the Coroner, 500 S. Grand Central Pkwy, Las Vegas, NV, 89155.

${ }^{4}$ Firearms and Toolmarks Identification Unit, Michigan State Police Forensic Laboratory, Lansing, MI.

${ }^{5}$ Clinical Labs of Hawaii, 99-193 Aiea Heights Drive, Aiea, HI, 96701.

${ }^{6}$ Georgia Bureau of Investigations, 3121 Panthersville Road, Decatur, GA, 30034.

${ }^{7}$ Biostatistics Department, University of Michigan School of Public Health, 1415 Washington Heights, Ann Arbor, MI, 48109-2029.

Corresponding author: LokMan Sung, M.D. E-mail: 1sung@waynecounty. com

*Supported by a grant from the University of Michigan, Department of Pathology AP Project Funding Committee.

Received 13 Nov. 2018; and in revised form 1 Feb. 2019, 7 Mar. 2019; accepted 8 Mar. 2019.
}

The presence of muzzle abrasions and dense concentrations of soot and gunpowder stippling on the skin surrounding entrance wounds provide forensic pathologists with confidence in assessing the range of fire. In the absence of these overt findings, this assessment can be difficult and fraught with error. For instance, bullet wipe, which may be composed of lubricant, soot, gunpowder, and dirt that is on a bullet's surface, can be deposited on the edges of an entrance wound and can mimic evidence of close-range fire. Because of these difficulties, some pathologists recommend microscopic examination of the entrance wound to detect gunpowder or soot unseen with the naked eye (3) while others caution against using histology to determine the range of fire (4).

While these previous prospective studies have examined the utility of routine light microscopic examination of gunshot wounds in assessing the range of fire, neither examined the macroscopic and microscopic features of gunshots fired at defined distances. This study explores the macroscopic and microscopic features of entrance and exit gunshot wounds fired from two commonly encountered handguns into human analog skin at four defined distances, in order to assess the utility of histology in the determination of the range of fire.

\section{Materials and Methods}

This study was conducted at the Forensic Crime Laboratory in the Detroit Public Safety Headquarters building in cooperation with the Michigan State Police. A Detective Lieutenant for the Michigan State Police, who currently serves as the supervisor of the Firearms and Toolmarks Identification Unit with 23-year law enforcement experience and 13-year forensic science experience, oversaw firearm safety measures and fired all the rounds. 


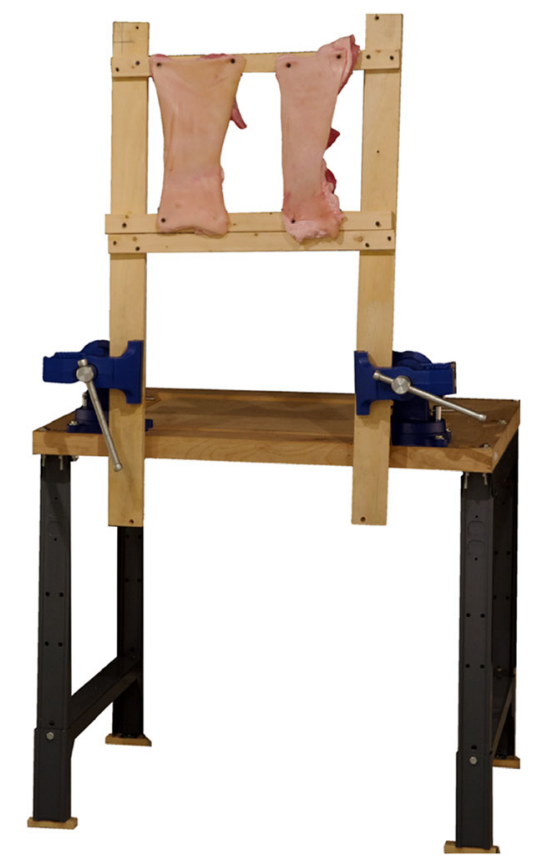

FIG. 1-Target stand supporting abdominal wall segments. [Color figure can be viewed at wileyonlinelibrary.com]
Three porcine body regions were selected for study: head, leg, and abdominal wall. Gunshots were fired at the front of the head to produce skin, superficial soft tissue, and bone sections for analysis. Shots were fired to the legs in order to produce both entrance and exit wounds and samples of skin and deep muscle for both wounds. At the point of gunshot wound entry and exit, the legs had a mean circumference of $31-1 / 2$ inches $(80 \mathrm{~cm})$ and a bullet track of 10 inches $(25.4 \mathrm{~cm})$. Porcine abdominal segments were used to sample skin and superficial adipose and soft tissue for analysis. Previous research groups have shown that porcine skin shares many anatomic, physiologic, histologic, histochemical, and immunohistochemical properties as human skin $(5,6)$.

The target stand used throughout the experiment consisted of a stable benchtop affixed with multi-jawed bench vises for securing the porcine body sections. A square frame constructed from wood furring strips provided support for the abdominal wall segments and a firm structure to clamp into the vises (Fig. 1).

The 0.22 Long Rifle (22LR) and 0.45 Automatic Colt Pistol (0.45 ACP) were selected for analysis, representing handgun calibers commonly encountered in our jurisdiction. A Smith \& Wesson ${ }^{\circledR}$ Model $41^{\mathrm{TM}}$ with a 5.5 -inch $(13.97 \mathrm{~cm})$ barrel that chambers the 22LR and a Springfield Armory ${ }^{\circledR} \mathrm{XD}^{\circledR} 0.45$ ACP Tactical with a 5 -inch $(12.7 \mathrm{~cm})$ barrel that chambers the 0.45 ACP served as reference handguns for the entire duration. Each

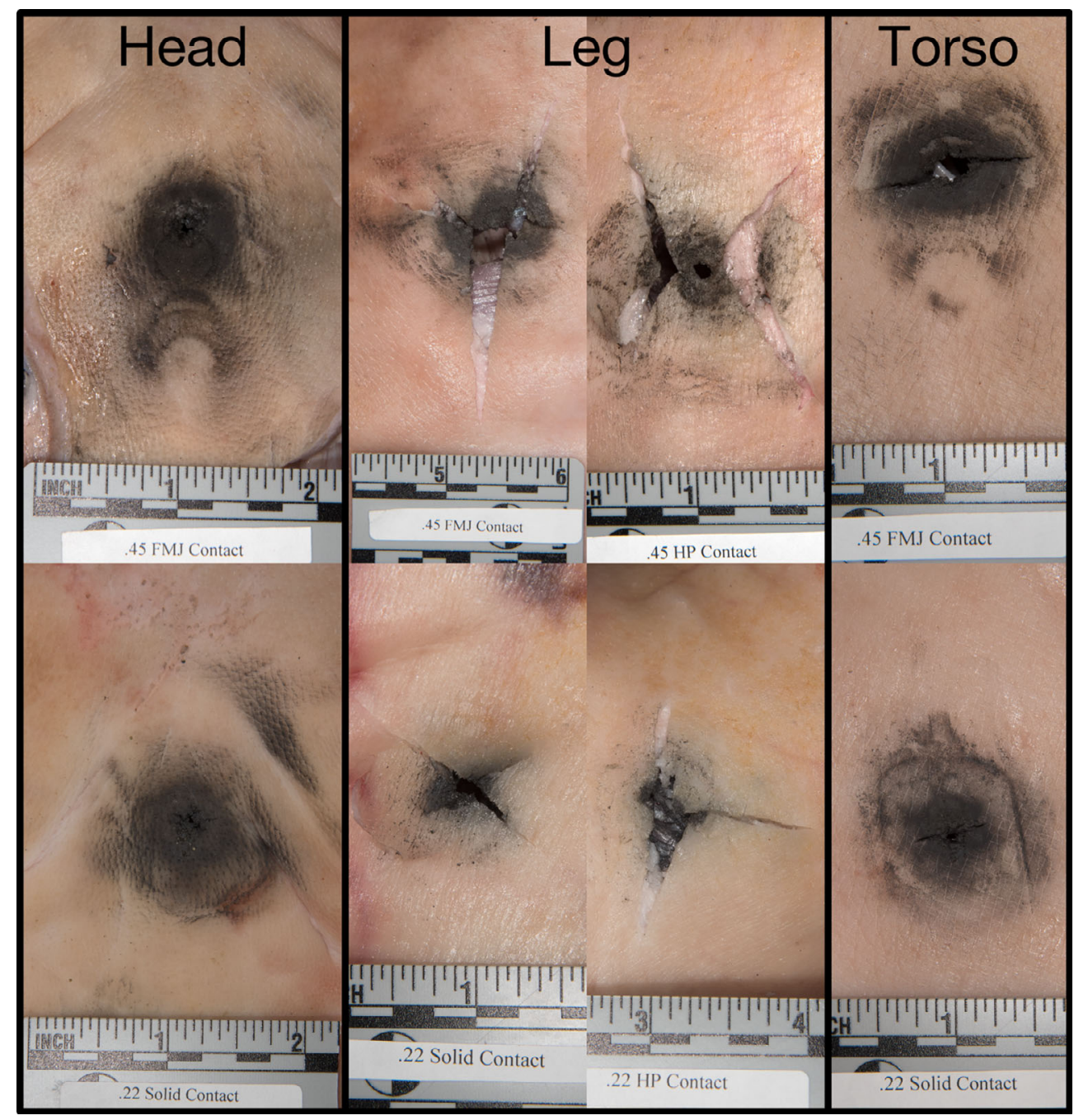




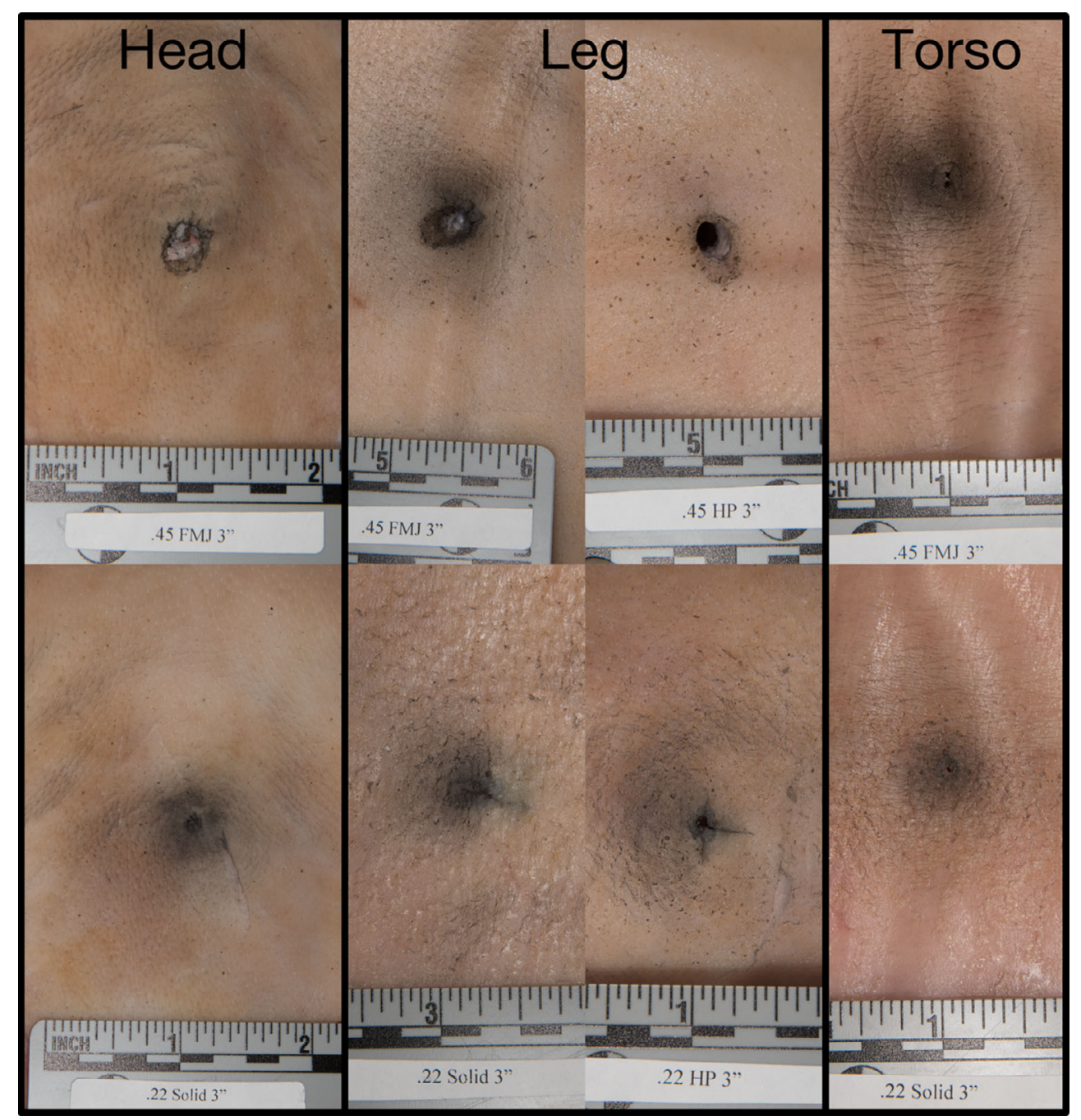

FIG. 3-Entrance gunshot wounds fired from three inches $(7.62 \mathrm{~cm})$. FMJ, full metal jacket; HP, hollow point. [Color figure can be viewed at wileyonlinelib rary.com]

firearm discharged its corresponding cartridges at four controlled muzzle-to-target distances: contact range, 3 inches $(7.62 \mathrm{~cm}), 1$ foot $(30.5 \mathrm{~cm})$, and 9 feet $(2.7 \mathrm{~m})$.

The $\mathrm{CCI}^{\circledR}$ Mini-Mag ${ }^{\mathrm{TM}}$ 22LR 40 grain solid and Remington ${ }^{\circledR}$ $\mathrm{UMC}^{\circledR} 0.45$ ACP 230 grain full-metal-jacket (FMJ) bullet configurations were used on all three tissue types. Additionally, $\mathrm{CCI}^{\circledR}$ Mini-Mag $^{\mathrm{TM}}$ 22LR 36 grain hollow-point (HP) and Speer Gold $\operatorname{Dot}{ }^{\circledR} 0.45$ ACP 230 grain HP bullet styles were fired at the porcine legs due to their increased propensity to carry large, visually observable, skin particles into tissue (7). Five shots were fired at each of the four distances to each of the three porcine segments for each bullet examined, and a Nikon D750 digital camera with an AF Zoom-NIKKOR 24-85 mm f/2.8-4D IF lens was used to document the morphology of the gunshot wounds and projectiles.

Histology sections were obtained on site immediately following each gunshot. Two sections of skin were taken perpendicular to each other at the margin of entrance wounds, as well as one section of either subcutaneous soft tissue from the head and abdominal wall shots or deep soft tissue for the leg shots. In addition, a section of the entrance perforation through the porcine frontal bone was sampled. For the exit wounds on the leg, a single section of skin from the margin of wound and a section of the deep soft tissue near the exit wound were taken. The tissue was fixed in $10 \%$ buffered formalin and bone was decalcified with Formical-2000 solution prior to processing. Slides were stained with hematoxylin and eosin stain.

Histology slides were examined by three American Board of Pathology-certified forensic pathologists employed full-time as medical examiners and by two fellows in an Accreditation Council for Graduate Medical Education-accredited fellowship in forensic pathology in a blinded fashion where the locations (entrance or exit) and types of firearm used were obscured. Slides were noted to be either positive or negative for black or dark brown material deposited on or within the tissue on each slide. All slides in which there was a discrepancy between the reviewers were re-examined in a blind fashion by the three forensic pathologists, and a consensus was reached.

\section{Results}

\section{Macroscopic Examination}

Contact Entrance Wounds-Figure 2 shows the entrance wounds created by both weapons fired in contact with the porcine skin at the three locations. All of the wounds had a muzzle imprint on the skin. The muzzle imprints were more defined on the head and torso, and this was true regardless of the caliber. All of the 


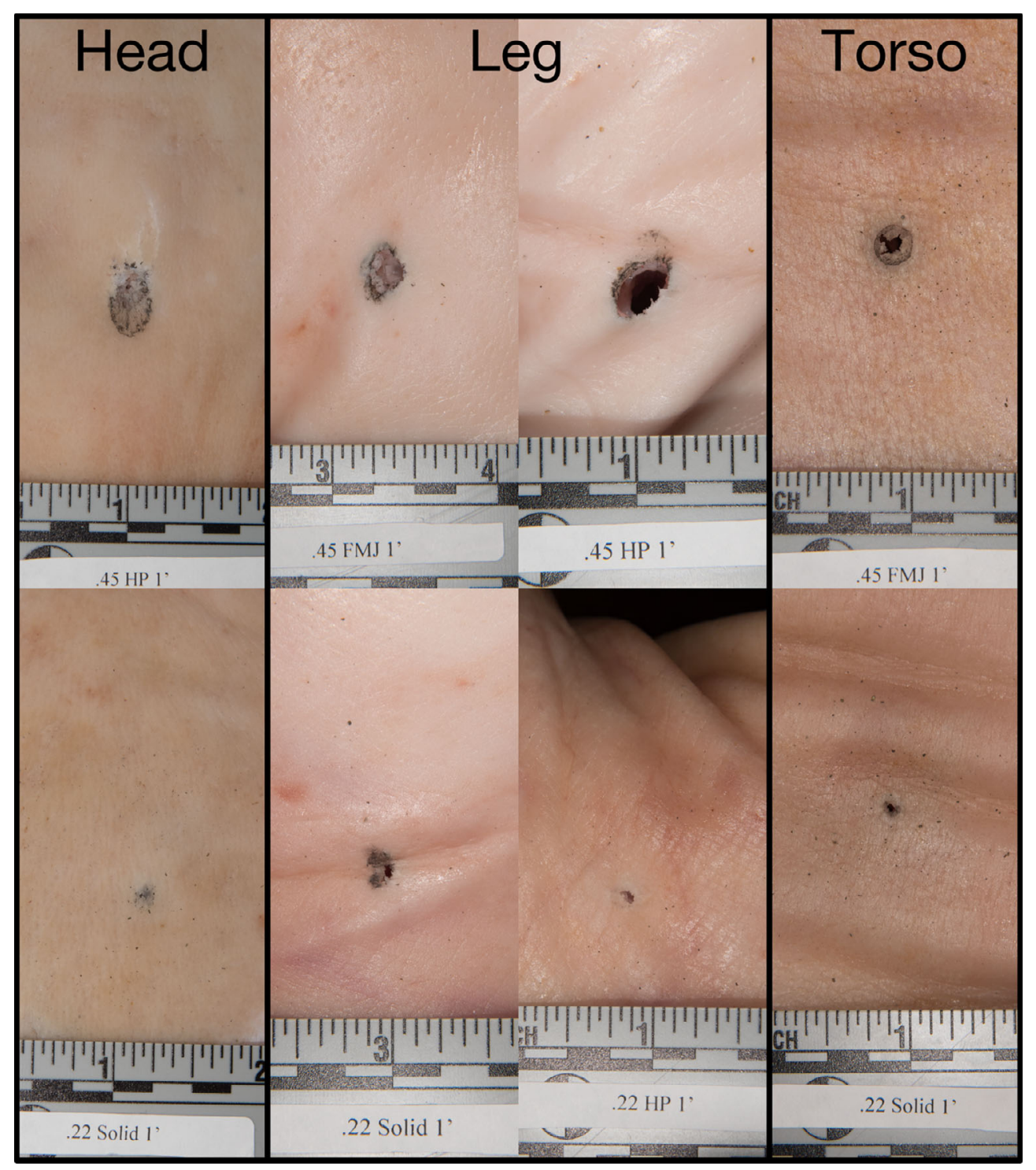

FIG. 4-Entrance gunshot wounds fired from one foot $(30.5 \mathrm{~cm})$. HP, hollow point; FMJ, full metal jacket. [Color figure can be viewed at wileyonlinelibra ry.com]

wounds had soot deposition on the surrounding skin. Regardless of caliber, soot deposition on the head and torso was greater in density but not diameter than on the legs, and the 0.45 caliber wounds had greater soot deposition than the 0.22 caliber wounds at all sites. Both hollow-point bullets produced less soot on the leg wounds than their solid and full metal jacket counterparts. Lacerations radiated from the wounds on the torso and leg, but were absent from the wounds on the head.

Entrance Wounds Fired from Three Inches $(7.62 \mathrm{~cm}$ )-Figure 3 shows the entrance wounds created by both calibers fired three inches $(7.62 \mathrm{~cm})$ from the porcine skin at the three locations. All wounds possessed appreciable bullet wipe, and it was more defined on the edges of the 0.45 caliber wounds regardless of location. All of the wounds had soot and gunpowder grains deposited on the surrounding skin in varying amounts, ranging from dense soot with little gunpowder on the 0.45 ACP FMJ shot on the torso to little soot and more gunpowder surrounding the 0.45 ACP HP shot on the leg. Both hollowpoint rounds produced less soot and deposited more gunpowder grains on the leg wounds than their solid and full metal jacket counterparts.

Entrance Wounds Fired from One Foot $(30.5 \mathrm{~cm}$ )-Figure 4 shows the entrance wounds created by both calibers fired one foot $(30.5 \mathrm{~cm})$ from the porcine skin at the three locations. All of the wounds displayed bullet wipe on the skin. Again, it was more defined on the edges of the 0.45 caliber wounds. Detection of bullet wipe around the 0.22 caliber wounds required magnification and scrutiny of photographs taken during experimentation. Grains of gunpowder were present on the skin surrounding all of the wounds in a faint and widely dispersed pattern. More gunpowder grains were present on the skin surrounding the 0.22 caliber wounds than the 0.45 caliber wounds.

Entrance Wounds Fired from Nine Feet $(2.7 \mathrm{~m})$-Figure 5 shows the entrance wounds created by both calibers fired nine feet $(2.7 \mathrm{~m})$ from the porcine skin at the three locations. Similar to the findings from a firing distance of one foot, all wounds displayed bullet wipe on the skin, was more defined on the 


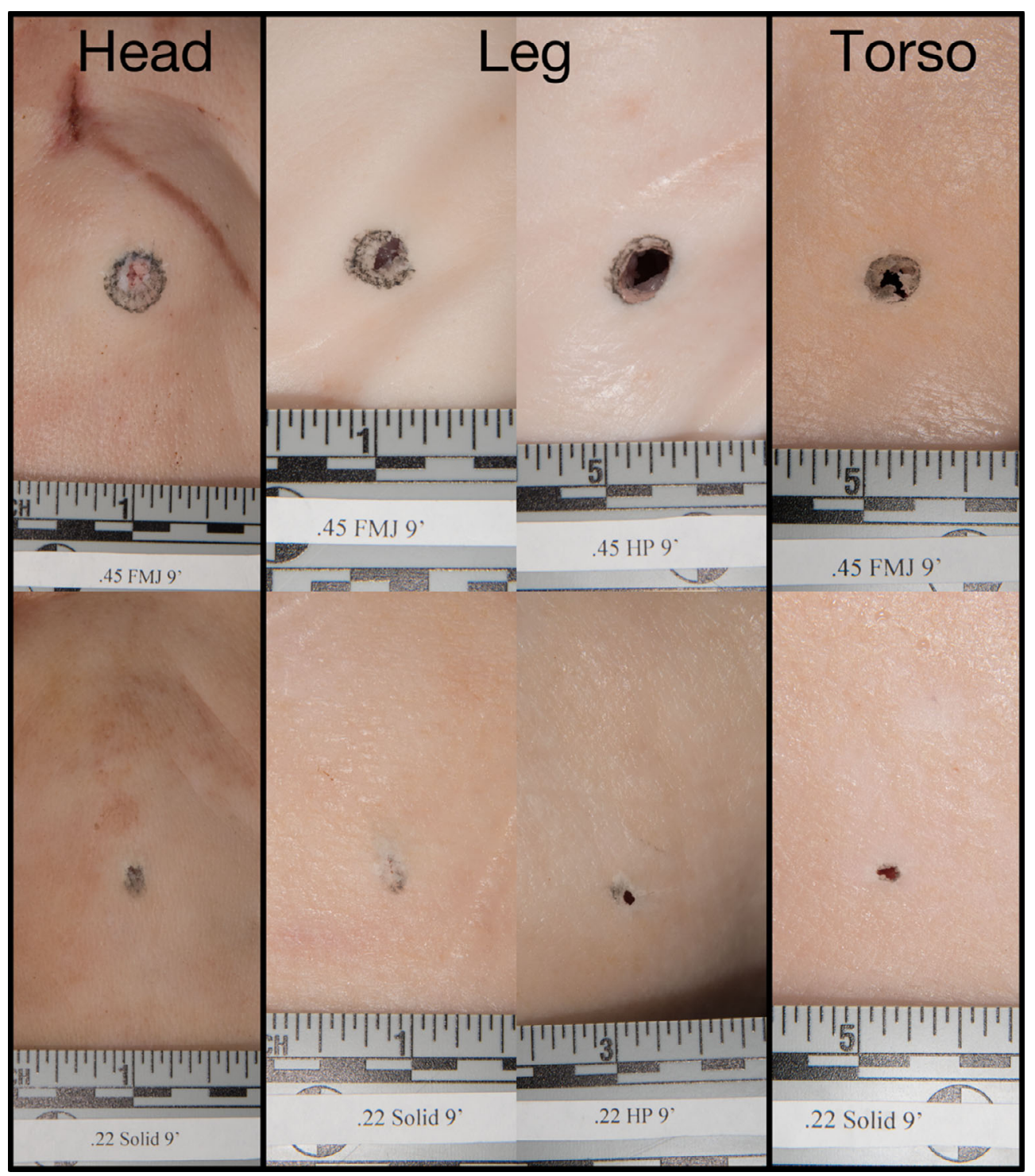

FIG. 5-Entrance gunshot wounds fired from nine feet $(2.7 \mathrm{~m})$. FMJ, full metal jacket; HP, hollow point. [Color figure can be viewed at wileyonlinelibrary.c om]

edges of the 0.45 caliber wounds, and was only visible around the 0.22 caliber wounds upon photographic magnification. No gunpowder grains were present on the skin surrounding any of these wounds.

Exit Wounds-Figure $6 a$ depicts the exit wounds on the porcine leg skin created by the 0.45 ACP FMJ and 0.45 ACP HP bullets at all four distances. Included in Figure $6 b$ are the exit wounds on the porcine leg skin created by the $0.22 \mathrm{LR}$ solid and 0.22 LR HP bullets at all four distances. All were irregular defects on the skin. Bullet wipe was identified around the exit wound from the contact 0.22 LR HP shot, only. No soot or gunpowder grains were detected surrounding any of these wounds.

\section{Microscopic Examination}

Contact Entrance Wounds-Table 1 summarizes the findings for all of the contact entrance gunshot wounds. Granular black material was embedded the skin and soft tissue of all wounds regardless of location or caliber, and both contact wounds to the head had similar material in the bone. Figure 7 shows the skin, superficial soft tissue, and bone histology of the contact entrance gunshot wound to the head created by the 0.45 ACP FMJ bullet.

Entrance Wounds Fired from Three Inches $(7.62 \mathrm{~cm})$ Table 2 summarizes the findings for all of the entrance gunshot wounds fired three inches $(7.62 \mathrm{~cm})$ from the porcine skin. All of the wounds showed granular black material deposition in the skin and soft tissue regardless of location or caliber, with the exception of the superficial soft tissue from the 0.22 LR solid shot to the torso. Figure 8 shows this negative soft tissue histology finding in the $0.22 \mathrm{LR}$ solid torso wound, as well as the positive skin, superficial soft tissue, and bone findings in the entrance gunshot wound to the head created by the 0.22 LR solid bullet fired from three inches $(7.62 \mathrm{~cm})$.

Entrance Wounds Fired from One Foot $(30.5 \mathrm{~cm}$ )-Table 3 summarizes the findings for all of the entrance gunshot wounds 
(a)

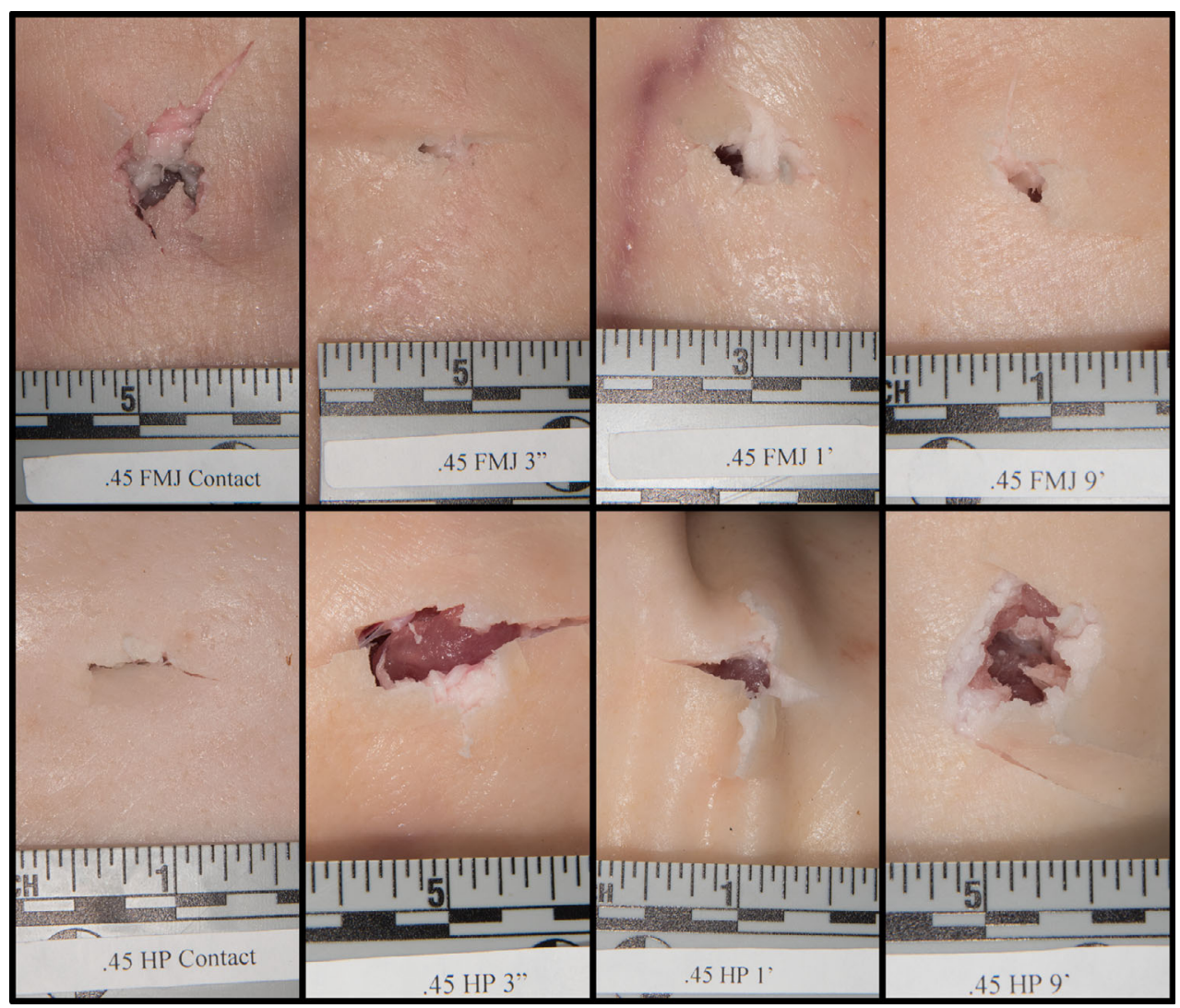

(b)

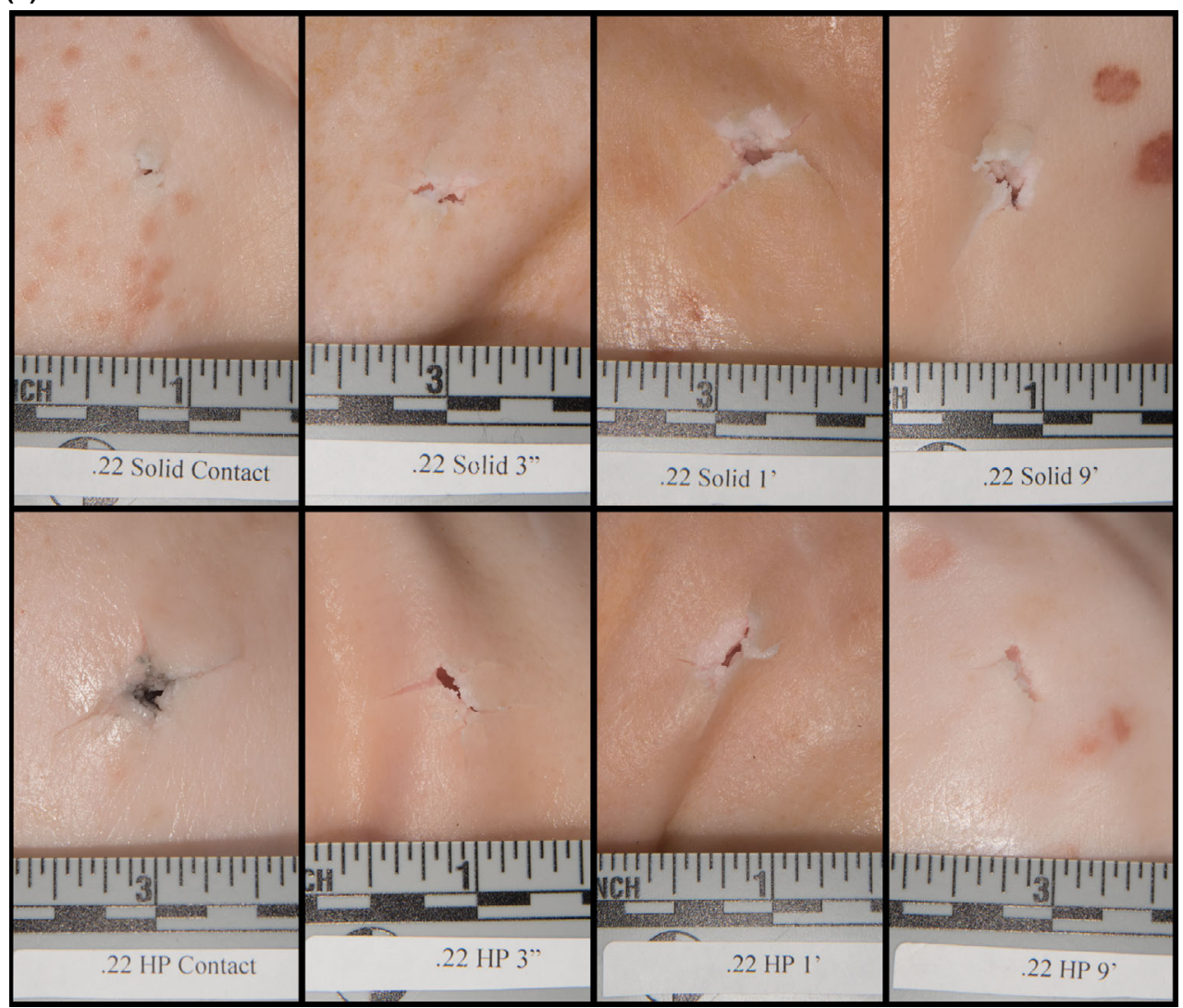

FIG. 6-(a) Exit gunshot wounds to leg from 0.45 caliber bullets at contact range, three inches $(7.62 \mathrm{~cm})$, one foot $(30.5 \mathrm{~cm})$, and nine feet $(2.7 \mathrm{~m})$. FMJ, full metal jacket; HP, hollow point. (b) Exit gunshot wounds to leg from 0.22 caliber bullets at contact range, three inches (7.62 cm), one foot (30.5 cm), and nine feet $(2.7 \mathrm{~m}) . \mathrm{HP}$, hollow point. [Color figure can be viewed at wileyonlinelibrary.com] 
TABLE 1-Findings for contact entrance gunshot wounds.

\begin{tabular}{|c|c|c|c|c|}
\hline \multirow[b]{2}{*}{ Location } & \multirow[b]{2}{*}{ Caliber } & \multirow[b]{2}{*}{$\begin{array}{l}\text { Gross assessment } \\
\text { of skin surface }\end{array}$} & \multicolumn{2}{|c|}{ Histology } \\
\hline & & & Tissue & $\begin{array}{c}\text { Presence of } \\
\text { black material }\end{array}$ \\
\hline \multirow[t]{6}{*}{ Head } & 0.45 FMJ & Dense soot & Skin & Positive \\
\hline & & & Superficial ST & Positive \\
\hline & & & Bone & Positive \\
\hline & 0.22 Solid & Dense soot & Skin & Positive \\
\hline & & & Superficial ST & Positive \\
\hline & & & Bone & Positive \\
\hline \multirow[t]{4}{*}{ Torso } & 0.45 FMJ & Dense soot & Skin & Positive \\
\hline & & & Superficial ST & Positive \\
\hline & 0.22 Solid & Dense soot & Skin & Positive \\
\hline & & & Superficial ST & Positive \\
\hline \multirow[t]{8}{*}{ Leg } & $0.45 \mathrm{FMJ}$ & Dense soot & Skin & Positive \\
\hline & & & Deep ST & Positive \\
\hline & $0.45 \mathrm{HP}$ & Dense soot & Skin & Positive \\
\hline & & & Deep ST & Positive \\
\hline & 0.22 Solid & Dense soot & Skin & Positive \\
\hline & & & Deep ST & Positive \\
\hline & $0.22 \mathrm{HP}$ & Dense soot & Skin & Positive \\
\hline & & & Deep ST & Positive \\
\hline
\end{tabular}

FMJ, full metal jacket; HP, hollow point; ST, soft tissue.

fired from one foot $(30.5 \mathrm{~cm})$. All of the 0.45 caliber wounds had positive skin and soft tissue findings, and the bone in the 0.45 ACP FMJ head shot was negative for black material. The 0.22 caliber wounds had varied results. The 0.22 LR solid head shot had black material in the superficial soft tissue and bone, but was negative in the skin. The $0.22 \mathrm{LR}$ solid shot to the torso had positive findings in both the skin and soft tissue, and both leg shots were negative. Figure 9 shows a composite of these varied histology findings in the 0.22 LR solid entrance wounds on the head, torso, and leg fired from one foot $(30.5 \mathrm{~cm})$.

Entrance Wounds Fired from Nine Feet $(2.7 \mathrm{~m}$ )—Table 4 summarizes the findings of all of the entrance wounds fired at nine feet $(2.7 \mathrm{~m})$. All 0.45 caliber wounds had positive findings in the skin and soft tissue, with the exception of one. The superficial soft tissue of 0.45 ACP FMJ head wound lacked appreciable foreign material, but the bone and skin did contain black substances. The 0.22 caliber wounds were negative for black material in all tissues on the torso and legs, while the skin, soft tissue, and bone from the 0.22 LR solid head shot were all positive for black material. Figure 10 shows the skin, soft tissue, and bone histology from these 0.45 ACP FMJ and 0.22 LR solid head wounds and the skin and deep soft tissue histology from the $0.22 \mathrm{LR}$ fired from nine feet $(2.7 \mathrm{~m})$.

Exit Wounds-Table 5 summarizes the histology findings of all of the exit wounds to the porcine legs. The deep soft tissue from the 0.45 caliber exit wounds was positive for black material with the exception of the $0.45 \mathrm{ACP}$ HP contact and 0.45 ACP FMJ three inch wounds $(7.62 \mathrm{~cm})$. The skin from all 0.45 caliber exit wounds did not contain any black material. The deep soft tissue from the 0.22 caliber exit wounds was positive for black material with the exception of the 0.22 LR HP three inch $(7.62 \mathrm{~cm})$ and $0.22 \mathrm{LR}$ HP nine foot $(2.7 \mathrm{~m})$ wounds. The skin from the 0.22 caliber exit wounds did not contain any black material with the exception of the 0.22 LR HP contact and 0.22 LR solid three inch $(7.62 \mathrm{~cm})$ wounds. Figure 11 is a composite of the histology of the skin and deep soft tissue from the 45 ACP FMJ and 0.22 LR HP contact exit wounds and the. 45 ACP HP and $0.22 \mathrm{LR}$ solid three inch $(7.62 \mathrm{~cm})$ exit wounds. Figure 12 is a composite of the skin and deep soft tissue histology of the 0.22 LR HP exit wounds fired from one foot $(30.5 \mathrm{~cm})$ and nine feet $(2.7 \mathrm{~m})$.

\section{Statistical Method}

Logistic regression models were used to study the association between factors (i.e., sample, bullet and distance) and the histologic positivity in the complete dataset. Significance is determined if $p<0.05$. All analyses were conducted using SAS (version 9.4, SAS Institute, Cary, NC).

In all models, histologic positivity was negatively associated with the numeric distance. When controlling for the bullets (22LR and 0.45 ACP aggregated) and ignoring the samples, the $p=0.05$ for the numeric distance. When controlling for the sample (skin, tissue, and bone aggregated) and ignoring the bullets, the $p=0.048$ for the numeric distance.

\section{Discussion}

Excluding compressed air weapons, handguns, rifles, and shotguns employs the combustion of gunpowder to propel projectiles down their respective barrels. Unburned, partially burned, or carbonaceous gunpowder may be deposited on the skin surrounding the entrance wound depending on the distance between the muzzle of the weapon and surface of the skin. Consumed gunpowder can result in carbonaceous gunpowder residue or soot being deposited on the skin if the muzzle of the weapon is close to the skin surface when fired. Equally

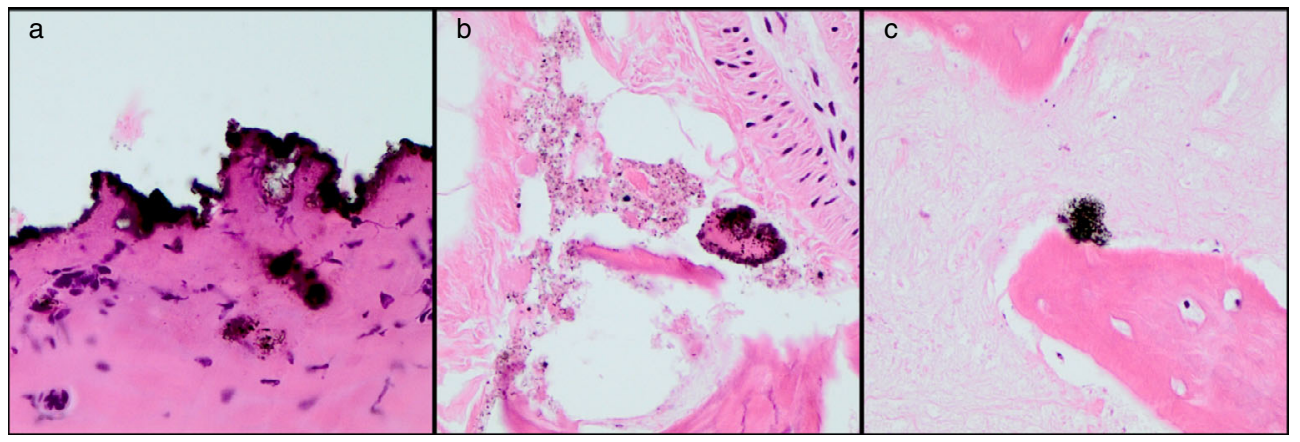

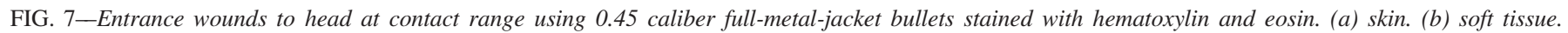
(c) bone. (original magnification $\times 400[a], \times 100[b], \times 400[c])$ [Color figure can be viewed at wileyonlinelibrary.com] 
important are injuries to the epidermal layers of the skin, or gunpowder stippling, caused by unburned or partially consumed gunpowder when the muzzle of the firearm discharges close to the skin surface.

TABLE 2-Findings for entrance gunshot wounds fired from three inches.

\begin{tabular}{|c|c|c|c|c|}
\hline \multirow[b]{2}{*}{ Location } & \multirow[b]{2}{*}{ Caliber } & \multirow[b]{2}{*}{$\begin{array}{l}\text { Gross assessment } \\
\text { of skin surface }\end{array}$} & \multicolumn{2}{|c|}{ Histology } \\
\hline & & & Tissue & $\begin{array}{c}\text { Presence of } \\
\text { black material }\end{array}$ \\
\hline \multirow[t]{6}{*}{ Head } & \multirow{3}{*}{0.45 FMJ } & Widespread soot & Skin & + \\
\hline & & + Gunpowder & Superficial ST & + \\
\hline & & + Bullet wipe & Bone & + \\
\hline & \multirow[t]{3}{*}{0.22 Solid } & Widespread soot & Skin & + \\
\hline & & + Gunpowder & Superficial ST & + \\
\hline & & + Bullet wipe & Bone & + \\
\hline \multirow[t]{4}{*}{ Torso } & \multirow[t]{2}{*}{0.45 FMJ } & Dense soot & Skin & + \\
\hline & & $\begin{array}{l}+ \text { Gunpowder } \\
+ \text { Bullet wipe }\end{array}$ & Superficial ST & + \\
\hline & \multirow[t]{2}{*}{0.22 Solid } & Widespread soot & Skin & + \\
\hline & & $\begin{array}{l}\text { + Gunpowder } \\
+ \text { Bullet wipe }\end{array}$ & Superficial ST & - \\
\hline \multirow[t]{8}{*}{ Leg } & \multirow[t]{2}{*}{$0.45 \mathrm{FMJ}$} & Widespread soot & Skin & + \\
\hline & & $\begin{array}{l}\text { + Gunpowder } \\
+ \text { Bullet wipe }\end{array}$ & Deep ST & + \\
\hline & \multirow[t]{2}{*}{$0.45 \mathrm{HP}$} & Some soot & Skin & + \\
\hline & & $\begin{array}{l}+ \text { Gunpowder } \\
+ \text { Bullet wipe }\end{array}$ & Deep ST & + \\
\hline & \multirow[t]{2}{*}{0.22 Solid } & Widespread soot & Skin & + \\
\hline & & $\begin{array}{l}\text { + Gunpowder } \\
+ \text { Bullet wipe }\end{array}$ & Deep ST & + \\
\hline & \multirow{2}{*}{$0.22 \mathrm{HP}$} & Widespread soot & Skin & + \\
\hline & & $\begin{array}{l}\text { + Gunpowder } \\
+ \text { Bullet wipe }\end{array}$ & Deep ST & + \\
\hline
\end{tabular}

FMJ, full metal jacket; HP, hollow point; ST, soft tissue.
Key to the estimation of the range of fire of gunshot wounds is the presence or absence of soot and/or gunpowder stippling on the skin surrounding the wound, and this assessment most commonly consists of gross or macroscopic examination of the wound and surrounding skin. Soot and gunpowder stippling are deposited on the skin in a manner similar to a can of spray paint, both being more dense and in a tighter pattern when fired closer to the skin and both becoming more dispersed in a wider pattern as the weapon in fired farther from the skin. When the soot and gunpowder stippling are densely deposited, there is little difficulty in their macroscopic visualization and interpretation. However, sparse deposition and wide dispersion on the skin create difficulty in visualization and assessment.

A common tool in the pathologists' diagnostic arsenal is microscopic examination of formalin-fixed tissue stained with hematoxylin and eosin (H\&E). The microscopic examination of entrance gunshot wounds has been addressed by a few in the forensic literature with mixed recommendations. Lorin de la Grandmaison in 2009 (3) found "smoke stains and/or interspersions of gunpowder" on the histologic examination of 35 gunshot wounds that did not show any macroscopic evidence of close-range firing and suggested taking histology of injuries. DiMaio in 1999 (2) concluded that although in intermediaterange wounds, gunpowder grains may be seen on histologic examination of the wound the assessment of the range of fire is best done macroscopically. Perez in 2012 (4) came to a similar conclusion as DiMaio after histologically examining 44 entrance gunshot wounds and finding that of the 27 that had no evidence of macroscopic soot or gunpowder nine had positive microscopic findings.

The cautious approach to reliance on the microscopic examination for the assessment of the range of fire has merit. Solitary or sparse gunpowder grains may be lost to sampling, embedding,

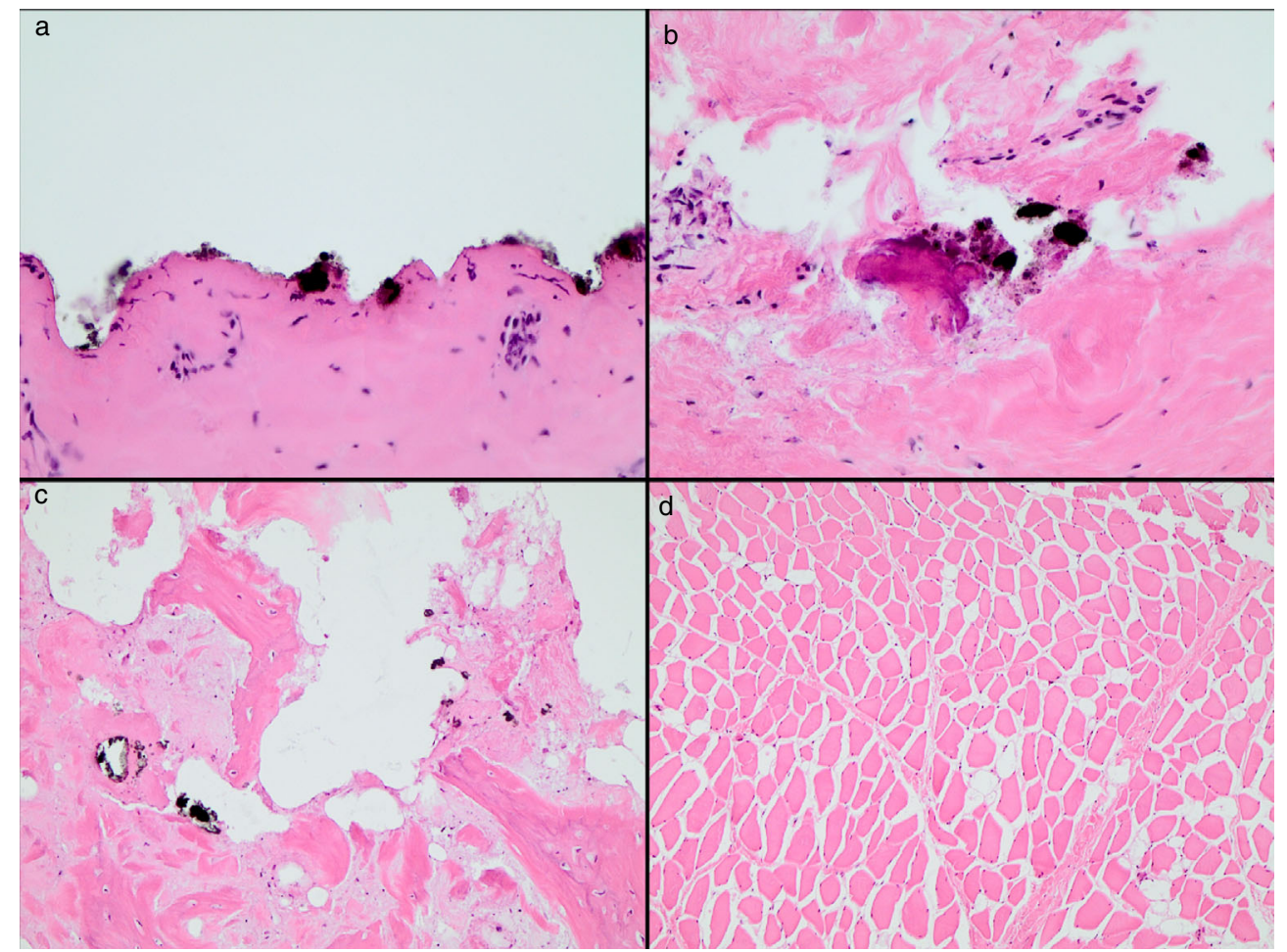

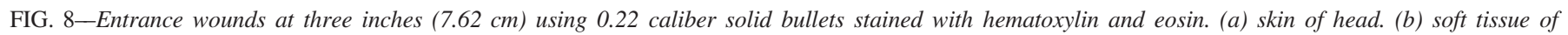
head. (c) bone of head. (d) soft tissue of torso. (original magnifcation $\times 400$ [a, $b$, and c], $\times 100$ [d]) [Color figure can be viewed at wileyonlinelibrary.com] 
and sectioning errors in making a microscopic slide. Soot, which is deposited on the skin and not embedded within it, may be rinsed and washed away or lost through the body's hemorrhaging and vital reaction or through fixation in a liquid (formalin).

TABLE 3-Findings for entrance gunshot wounds fired from one foot.

\begin{tabular}{|c|c|c|c|c|}
\hline \multirow[b]{2}{*}{ Location } & \multirow[b]{2}{*}{ Caliber } & \multirow[b]{2}{*}{$\begin{array}{l}\text { Gross assessment of } \\
\text { skin surface }\end{array}$} & \multicolumn{2}{|c|}{ Histology } \\
\hline & & & Tissue & $\begin{array}{c}\text { Presence of } \\
\text { black material }\end{array}$ \\
\hline \multirow[t]{6}{*}{ Head } & \multirow[t]{3}{*}{0.45 FMJ } & - Soot & Skin & + \\
\hline & & Faint Gunpowder & Superficial ST & + \\
\hline & & + Bullet wipe & Bone & - \\
\hline & \multirow[t]{3}{*}{0.22 Solid } & - Soot & Skin & - \\
\hline & & Faint Gunpowder & Superficial ST & + \\
\hline & & + Bullet wipe & Bone & + \\
\hline \multirow[t]{4}{*}{ Torso } & \multirow[t]{2}{*}{0.45 FMJ } & - Soot & Skin & + \\
\hline & & $\begin{array}{l}\text { Faint Gunpowder } \\
+ \text { Bullet wipe }\end{array}$ & Superficial ST & + \\
\hline & \multirow[t]{2}{*}{0.22 Solid } & - Soot & Skin & + \\
\hline & & $\begin{array}{l}\text { Faint Gunpowder } \\
+ \text { Bullet wipe }\end{array}$ & Superficial ST & + \\
\hline \multirow[t]{8}{*}{ Leg } & \multirow[t]{2}{*}{0.45 FMJ } & - Soot & Skin & + \\
\hline & & $\begin{array}{l}\text { Faint Gunpowder } \\
+ \text { Bullet wipe }\end{array}$ & Deep ST & + \\
\hline & \multirow{2}{*}{$0.45 \mathrm{HP}$} & - Soot & Skin & + \\
\hline & & $\begin{array}{l}\text { Faint Gunpowder } \\
+ \text { Bullet wipe }\end{array}$ & Deep ST & + \\
\hline & \multirow[t]{2}{*}{0.22 Solid } & - Soot & Skin & - \\
\hline & & $\begin{array}{l}\text { Faint Gunpowder } \\
+ \text { Bullet wipe }\end{array}$ & Deep ST & - \\
\hline & \multirow{2}{*}{$0.22 \mathrm{HP}$} & - Soot & Skin & - \\
\hline & & $\begin{array}{l}\text { Faint Gunpowder } \\
+ \text { Bullet wipe }\end{array}$ & Deep ST & - \\
\hline
\end{tabular}

FMJ, full metal jacket; HP, hollow point; ST, soft tissue.
One of the biggest obstacles to the microscopic assessment of close-range firing is bullet wipe. Bullet wipe can be an admixture of lubricant, soot, gunpowder, and dirt that is on a bullet's surface and may be deposited on the edges of an entrance wound. It is macroscopically differentiated from close-range fire as it is sharply demarcated on the skin immediately around the wound. Because bullet wipe is on the surface of a bullet, its deposition is not dependent on the range of fire and it can be seen in the edges of a wound and in the wound track of a gunshot wound fired from any distance. Bullet wipe is also seen on microscopic examination of gunshot wounds regardless of the range of fire, as noted by DiMaio in 2007 (8).

The other major obstacle is the lack of histologic criterion for the distinction between soot, gunpowder, and bullet wipe on H\&E-stained slides. In this study, the microscopically observed black material possessed a granular nature. Adelson in 1961 (9) described "powder residue as black amorphous clumps or as scattered collections of brown-yellow needles," and Cummings in 2011 (10) noted that brown/black granular material in the histology of a contact entrance wound is from both the distance of the shot and from direct transfer from the surface of the bullet. While microscopic examination can be used to detect this foreign material, it provides no insight as to what the black, brown, or yellow material actually represents. It is also incorrect to limit the appearance of soot, gunpowder, and bullet wipe to these three morphologies. There are currently hundreds of ammunition manufactures, and while the chemical components of the propellants used many be similar, the makeup and specific compositions within the gunpowders are commonly confidential and proprietary information. It cannot be known if the combustion of one manufacturer's powder and its deposition on the skin or within the wound track will be similar to another manufacturer's, or if the combusted material has distinct morphologies that allow for easy segregation from other artifacts, such as formalin

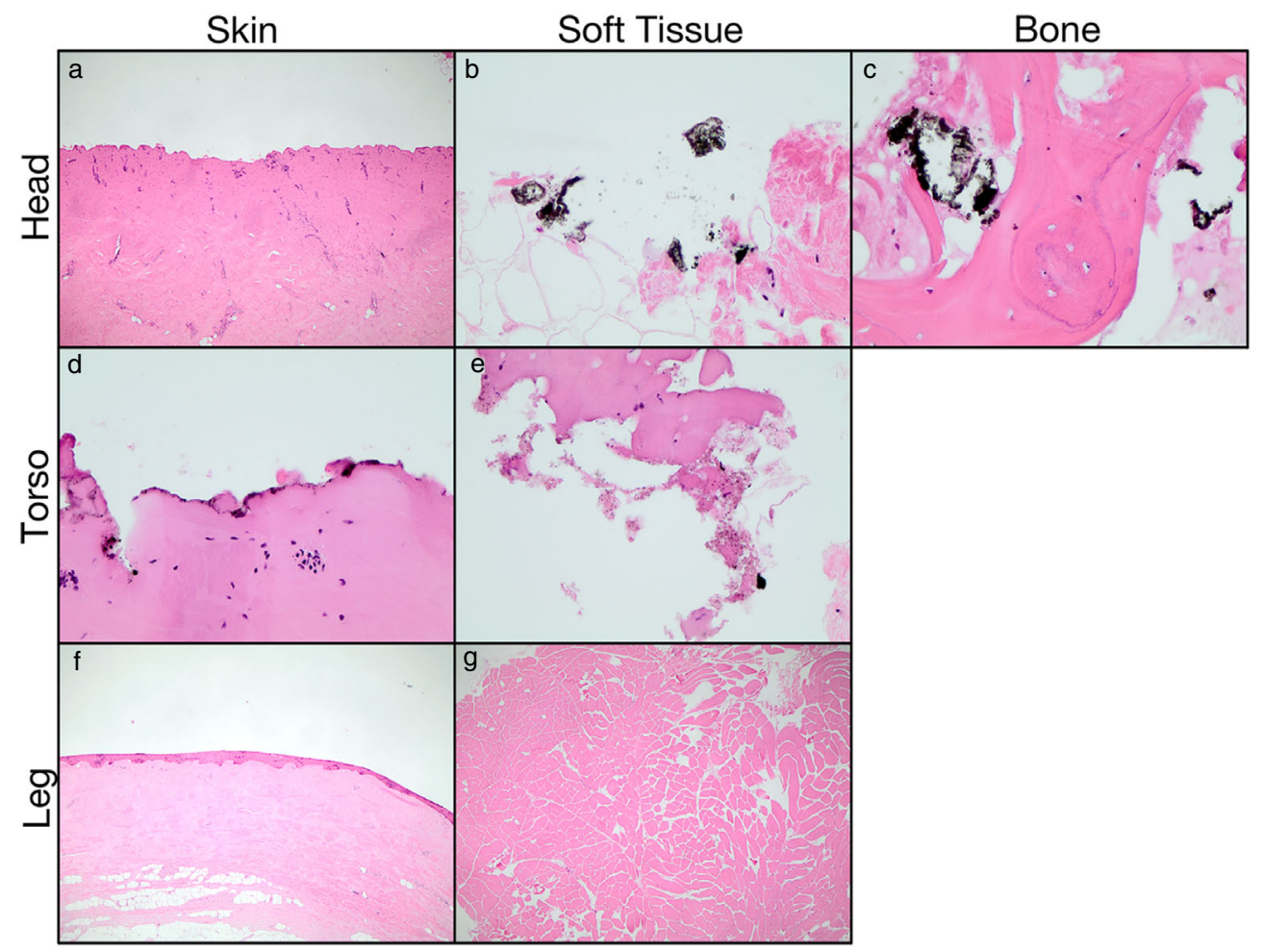

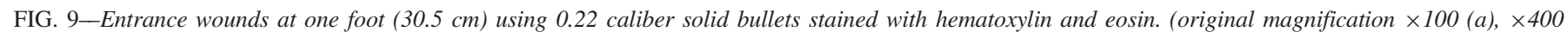
$(b-e), \times 100(f$ and $g))$ [Color figure can be viewed at wileyonlinelibrary.com] 
pigment, hemosiderin, melanocytes, and hair. It is also unknown as to what depth the combusted propellant of one ammunition will travel into tissue as compared to other types of ammunition

TABLE 4-Findings for entrance gunshot wounds fired from nine feet.

\begin{tabular}{|c|c|c|c|c|}
\hline \multirow[b]{2}{*}{ Location } & \multirow[b]{2}{*}{ Caliber } & \multirow[b]{2}{*}{$\begin{array}{c}\text { Gross assessment of } \\
\text { skin surface }\end{array}$} & \multicolumn{2}{|c|}{ Histology } \\
\hline & & & Tissue & $\begin{array}{c}\text { Presence of } \\
\text { black material }\end{array}$ \\
\hline \multirow[t]{6}{*}{ Head } & \multirow[t]{3}{*}{0.45 FMJ } & - Soot & Skin & + \\
\hline & & -Gunpowder & Superficial ST & - \\
\hline & & + Bullet wipe & Bone & + \\
\hline & \multirow[t]{3}{*}{0.22 Solid } & - Soot & Skin & + \\
\hline & & -Gunpowder & Superficial ST & + \\
\hline & & + Bullet wipe & Bone & + \\
\hline \multirow[t]{4}{*}{ Torso } & \multirow[t]{2}{*}{0.45 FMJ } & - Soot & Skin & + \\
\hline & & $\begin{array}{l}\text {-Gunpowder } \\
+ \text { Bullet wipe }\end{array}$ & Superficial ST & + \\
\hline & \multirow[t]{2}{*}{0.22 Solid } & - Soot & Skin & - \\
\hline & & $\begin{array}{l}\text {-Gunpowder } \\
+ \text { Bullet wipe }\end{array}$ & Superficial ST & - \\
\hline \multirow[t]{8}{*}{ Leg } & \multirow[t]{2}{*}{0.45 FMJ } & - Soot & Skin & + \\
\hline & & $\begin{array}{l}\text {-Gunpowder } \\
+ \text { Bullet wipe }\end{array}$ & Deep ST & + \\
\hline & \multirow[t]{2}{*}{$0.45 \mathrm{HP}$} & - Soot & Skin & + \\
\hline & & $\begin{array}{l}\text {-Gunpowder } \\
+ \text { Bullet wipe }\end{array}$ & Deep ST & + \\
\hline & \multirow[t]{2}{*}{0.22 Solid } & - Soot & Skin & - \\
\hline & & $\begin{array}{l}\text {-Gunpowder } \\
+ \text { Bullet wipe }\end{array}$ & Deep ST & - \\
\hline & \multirow[t]{2}{*}{$0.22 \mathrm{HP}$} & - Soot & Skin & - \\
\hline & & $\begin{array}{l}\text {-Gunpowder } \\
+ \text { Bullet wipe }\end{array}$ & Deep ST & - \\
\hline
\end{tabular}

FMJ, full metal jacket; HP, hollow point; ST, soft tissue.
TABLE 5-Histology findings for exit gunshot wounds to the leg.

\begin{tabular}{|c|c|c|c|}
\hline Distance & Caliber & Tissue & $\begin{array}{c}\text { Presence of } \\
\text { black material }\end{array}$ \\
\hline \multirow{8}{*}{ Contact } & \multirow[t]{2}{*}{$0.45 \mathrm{FMJ}$} & Skin & - \\
\hline & & Deep soft tissue & + \\
\hline & \multirow[t]{2}{*}{$0.45 \mathrm{HP}$} & Skin & - \\
\hline & & Deep soft tissue & - \\
\hline & \multirow[t]{2}{*}{0.22 Solid } & Skin & - \\
\hline & & Deep soft tissue & + \\
\hline & \multirow{2}{*}{$0.22 \mathrm{HP}$} & Skin & + \\
\hline & & Deep soft tissue & + \\
\hline \multirow{8}{*}{ Three inches $(7.62 \mathrm{~cm})$} & \multirow{2}{*}{$0.45 \mathrm{FMJ}$} & Skin & - \\
\hline & & Deep Soft Tissue & - \\
\hline & \multirow[t]{2}{*}{$0.45 \mathrm{HP}$} & Skin & - \\
\hline & & Deep soft tissue & + \\
\hline & \multirow{2}{*}{0.22 Solid } & Skin & + \\
\hline & & Deep soft tissue & + \\
\hline & \multirow[t]{2}{*}{$0.22 \mathrm{HP}$} & Skin & - \\
\hline & & Deep soft tissue & - \\
\hline \multirow{8}{*}{ One foot $(30.5 \mathrm{~cm})$} & \multirow[t]{2}{*}{$0.45 \mathrm{FMJ}$} & Skin & - \\
\hline & & Deep soft tissue & + \\
\hline & \multirow[t]{2}{*}{$0.45 \mathrm{HP}$} & Skin & - \\
\hline & & Deep soft tissue & + \\
\hline & \multirow[t]{2}{*}{0.22 Solid } & Skin & - \\
\hline & & Deep soft tissue & + \\
\hline & \multirow{2}{*}{$0.22 \mathrm{HP}$} & Skin & - \\
\hline & & Deep soft tissue & + \\
\hline \multirow[t]{8}{*}{ Nine feet $(2.7 \mathrm{~m})$} & \multirow[t]{2}{*}{$0.45 \mathrm{FMJ}$} & Skin & - \\
\hline & & Deep soft tissue & + \\
\hline & \multirow[t]{2}{*}{$0.45 \mathrm{HP}$} & Skin & - \\
\hline & & Deep soft tissue & + \\
\hline & \multirow[t]{2}{*}{0.22 Solid } & Skin & - \\
\hline & & Deep soft tissue & + \\
\hline & \multirow[t]{2}{*}{$0.22 \mathrm{HP}$} & Skin & - \\
\hline & & Deep soft tissue & - \\
\hline
\end{tabular}

FMJ, full metal jacket; HP, hollow point.

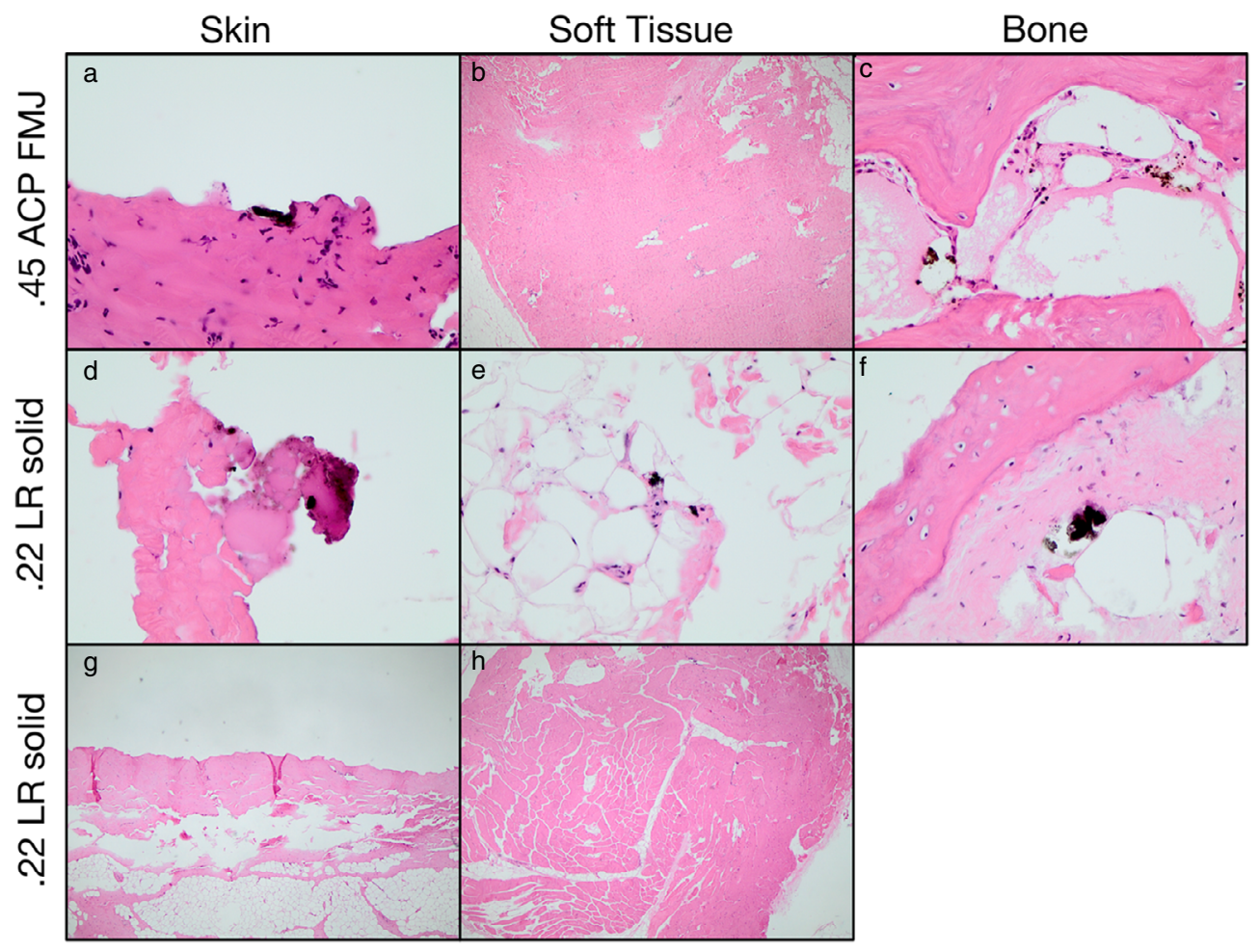

FIG. 10-Entrance wounds at nine feet $(2.7 \mathrm{~m})$ stained with hematoxylin and eosin. ACP, Automatic Colt Pistol; FMJ, full metal jacket; LR, long rifle. (original magnification $\times 400[a$, and $c-f], \times 100[b, g$, and $h]$ ] [Color figure can be viewed at wileyonlinelibrary.com] 


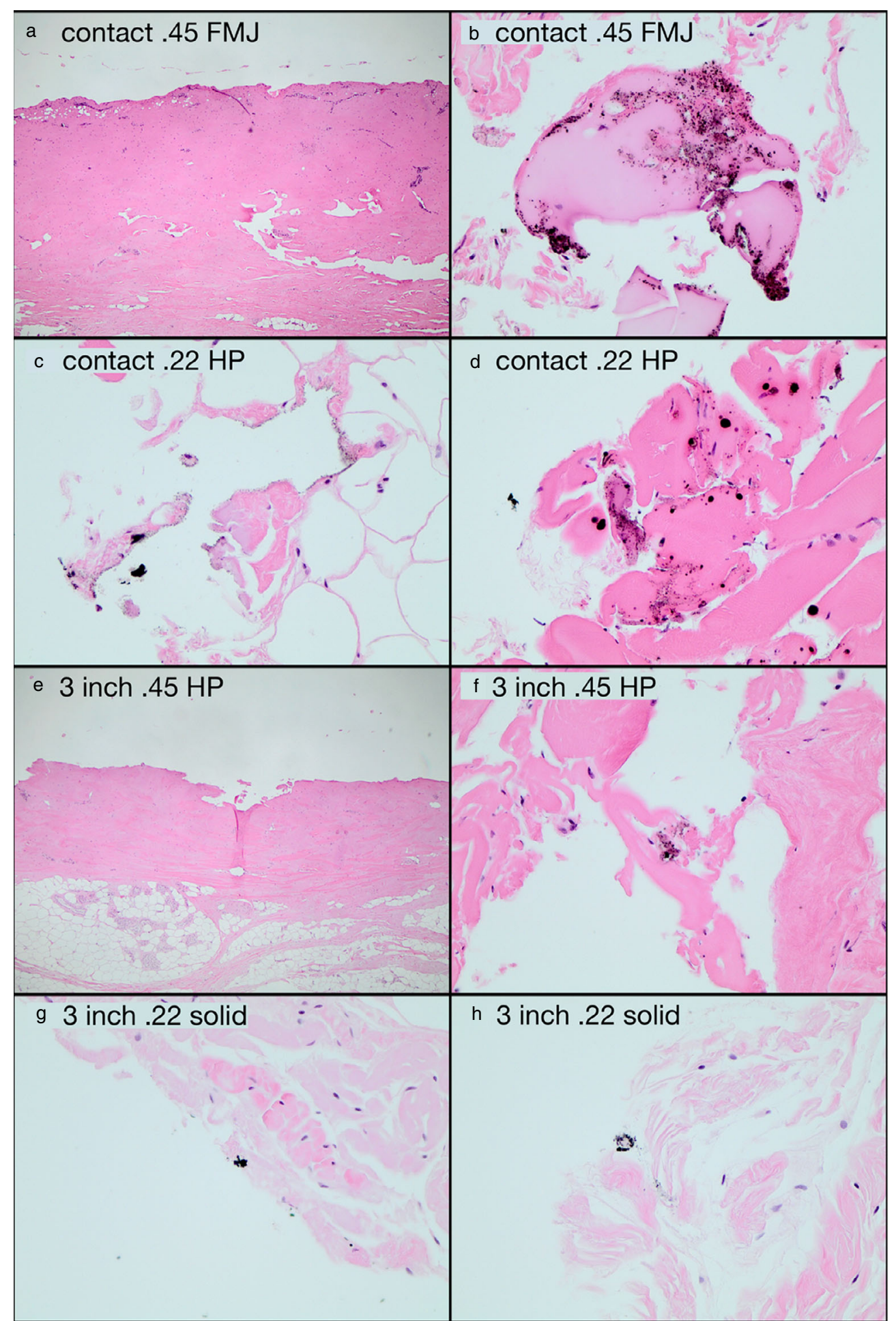

FIG. 11-Exit wounds from contact range and three inches $(30.5 \mathrm{~cm})(7.62 \mathrm{~cm})$ stained with hematoxylin and eosin. FMJ, full metal jacket; HP, hollow point. (original magnification $\times 100$ [a and $e], \times 400[b-d$, and $f-h]$ ) [Color figure can be viewed at wileyonlinelibrary.com]

at various muzzle-to-target distances. The lack of a compendium illustrating the different gunpowders and their combustion products is a barrier to constructing histologic criteria. In the absence of criteria, the only objective assessment that can be made is the presence or absence of these materials in the wound. Perez (4) cited this lack of criterion and ultimate inability to differentiate the range of fire on histologic assessment of gunshot wounds.
The histologic examination of exit gunshot wounds is equally confusing, as bullet wipe, soot, and gunpowder can all be present in exit wounds. Bullet wipe can be transferred to exit wounds the same as entrance wounds, and as Reddy pointed out in 2011 (11), even soot may be seen in exit wounds if they are located close to the entrance wounds. Perez (4) found positive histologic findings in 24 of the exit wounds examined in his 
Skin

Soft Tissue

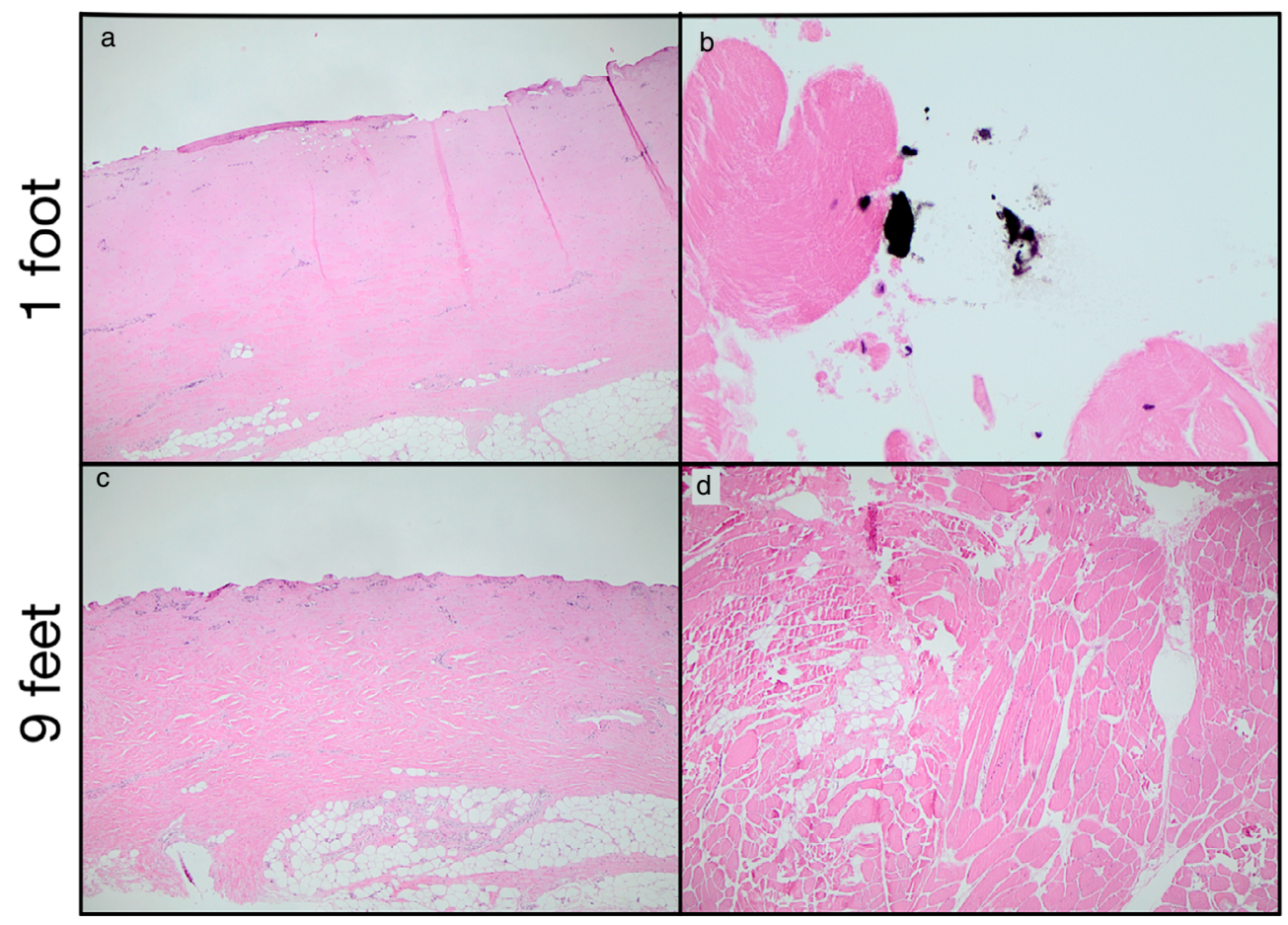

FIG. 12-Exit wounds from one foot $(30.5 \mathrm{~cm})$ and nine feet $(2.7 \mathrm{~m})$ using 0.22 caliber hollow-point bullets stained with hematoxylin and eosin. (original magnification $\times 100$ [ $a$ and $c], \times 400$ [ $b$ and $d]$ ]) [Color figure can be viewed at wileyonlinelibrary.com]

study, and powder particles are described in the histology of exit wounds by Dettmeyer in 2011 (12). It is not known what these particles represent, again due to the inability to histologically differentiate between bullet wipe, soot, and gunpowder.

This study is the first to examine the macroscopic and microscopic features of entrance and exit gunshot wounds fired from two commonly encountered handguns into human tissue analogs at four defined distances, in order to assess the utility of histology in the determination of the range of fire.

The microscopic examination of the entrance gunshot wounds did not correlate to the macroscopic examination of the wounds in our study. Black or dark brown material was noted in the skin of all 0.45 caliber entrance wounds and was present in almost all of the soft tissue and bone from the 0.45 caliber entrance wounds regardless of the distance the shot was fired. The histology from the 0.22 caliber entrance wounds produced more varied results at all known distances in the skin, soft tissue, and bone sections. There was no difference between the full metal jacket/solid and hollow-point rounds for either caliber.

In statistically analyzing the microscopic results, for all models used, the rate of histologic positivity for black material decreased as the distance between the muzzle of firearm and target increased. However, the ability to use histologic positivity to predict distance was either not statistical significance or equivocal. When controlling for the sample source and ignoring the bullet caliber, the $p=0.048$ for the muzzle-to-target distances producing histologic positivity. With the significance threshold set at $p<0.05$, the $p$-value is quantitatively less than 0.05 , but it is so close to 0.05 that its true significant is in question. Disregarding the caliber of the bullet in this model is appropriate due to many factors, such as the inability to recover bullets from through-and-through gunshot wounds, deformation of recovered bullets, and similar caliber bullets originating from cartridges containing differing amounts of powder (9 mm vs. 0.357 magnum).

The microscopic examination of the exit gunshot wounds in this study also produced varied results that did not correlate to the macroscopic examination of the wounds or the known fired distance. The deep soft tissues for both calibers were positive for black material, with exceptions noted for each distance and both calibers. The skin of all of the exit wounds was negative, except for 0.22 caliber wounds fired at contact range and from three inches. While all of the tissue submitted for histology were obtained and prepared in the same fashion by the same physicians, sampling error may have a contribution in these results. However, it more likely reflects the unpredictable amount of materials concentrating on the surface of a bullet that ultimately ends as bullet wipe. By the nature of its manufacturing, some ammunition, such as the rimfire 22LR, may have a higher likelihood of producing bullet wipe. As briefly discussed by DiMaio (2), the priming compound embedded within the rim of this round, bullets commonly made of lead with only a thin copper coating, and wax and lubricants on the bullet, makes the 22LR ammunition distinctly different from conventional centerfire rounds.

There were limitations in performing this study. The comparison of entrance and exit wounds involved using porcine legs. The mean wound track length between the entrance and exit wounds on the porcine leg was 10 inches $(25.4 \mathrm{~cm})$, with the tracks passing through predominantly skin and muscle. What could not be assessed using this method was what the effects of perforating the axial skeleton and visceral organs with their differing elastic qualities would have on the transfer of bullet wipe, soot, and gunpowder. It is reasonable that transfer of these materials would decrease. However, due to restrictions of the United States Department of Agriculture (USDA) on the sale of 
slaughtered carcasses containing intact visceral organs, and the USDA's restrictions on the purchase of some internal organs, a large supply of viscera-intact carcasses to address this question could not be obtained.

Another limitation stems from the selection of porcine body segments as substrates. As DeBeer (5) indicated, an important difference between porcine and human skin is a thinner stratum granulosum, greater dispersal of apocrine sweat glands, and decreased size and density of sebaceous glands. The increased formation of keratin and keratohyalin in the thicker granular cell layer in human skin combined with greater numbers of glandular structures may attenuate the transmission of bullet wipe, soot, and gunpowder into the underlying soft tissue. Additionally, all of the porcine body segments were from harvested pigs intended for human consumption and lacked the ability to display vital reaction to injury and hemorrhage from the wound. This study could not examine whether these physiologic responses would have sufficient force to physically remove the materials from the wound track or obfuscate their detection macroscopically or microscopically.

We conclude that, due to the lack of criteria for the histologic differentiation between soot, gunpowder, and bullet wipe on H\&E-stained slides, microscopic examination of gunshot wounds has very limited utility in assessing the range of fire, even when fired from known distances. The performance of histology on gunshot wounds should be used judiciously and with welldefined parameters, such as when functioning as a secondary method of injury documentation. Akin to the selection of immunohistochemical stains, a careful understanding of the limitations of examining gunshot wounds microscopically, whether at a questioned site of bullet entrance or exit, and comprehension of the potential for producing confounding results is required. We assert that the best tool for the forensic pathologist to assess the range of fire of a gunshot wound is still macroscopic examination of the wound.

\section{References}

1. Spitz WU. Medicolegal investigation of death. Springfield, IL: Charles C. Thomas Publisher, 2006;607-42.

2. DiMaio VJM. Gunshot wounds: practical aspects of firearms, ballistics, and forensic techniques. Boca Raton, FL: CRC Press, 1999;339-40.

3. Lorin de la Grandmaison G, Charlier P, Durigon M. Usefulness of systemic histological examination in routine forensic autopsy. J Forensic Sci 2010;55(1):85-8.

4. Perez D, Molina K. The utility of routine histological examination of gunshot wounds. Am J Forensic Med Pathol 2012;33(3):231-3.

5. DeBeer S, Le Luduec JB, Kaiserlain D, Laurent P, Nicolas JF, Dubois $\mathrm{B}$, et al. Comparative histology and immunohistochemistry of porcine versus human skin. Eur J Dermatol 2013;23(4):456-66.

6. Haag M, Haag L. Skin perforation and skin stimulants. Association of Firearm and Tool Mark Examiners (AFTE) Journal 2002;34(3): $268-86$.

7. Perdekamp M, Vennemann B, Mattern D, Serr A, Pollak S. Tissue defect at the gunshot entrance wound: what happens to the skin? Int J Legal Med 2005;119:271-22.

8. DiMaio VJM, Dans S. Handbook of forensic pathology. Boca Raton, FL: CRC Press, 2007;143-4.

9. Adelson L. A microscopic study of dermal gunshot wounds. Am J Clin Pathol 1961;35(5):393-402.

10. Cummings P, Trelka D, Springer K. Atlas of forensic histopathology. Cambridge, NY: Cambridge University Press, 2011;82.

11. Reddy K, Lowenstein E. Forensics in dermatology: Part II. J Am Acad Dermatol 2011;64(5):811-24.

12. Dettmeyer R. Forensic histopathology: fundamentals of perspectives. Cham, Switzerland: Springer International Publishing AG, 2011;51-2. 